\title{
History and semantics of origins: Between nature, artifice and beliefs $\left(18^{\text {th }}-19^{\text {th }}\right.$ century)
}

\author{
Claude Blanckaert ${ }^{\mathrm{a}}$ \\ CNRS - Centre Alexandre Koyré, France
}

\section{The passion for origins}

What a formidable question, that of "origins." Or rather a strange pursuit that is commonly thought to be inscribed from time immemorial in the depths of the human soul, like a quest for meaning equally satisfied by age-old myths, be they religious or not, and by the demands of Reason. Do we speak of an anthropological constant? This imperious need to go back to the root of things would arise from deep inside the human psyche, like a will to power of mankind who seeks to place itself in a spatio-temporal continuum to ward off the fear of death. "Origins are initiatives, whose example strengthens us" [1: 177]. In short, anything is better than insignificance.

The "mystery" surrounding the Origins, as it is sometimes said, would have arisen "with the dawn of thought" at a certain point in our evolution. As André Leroi-Gourhan [2: 9-10] explains, Neanderthal preceded the prehistorian who "delve[s] into the recesses of the earth like a child taking a toy to pieces." Whatever the distance that separates them, he continues, they are close in spirit:

"No great effort is required to discern the same feelings, intact though still as vague, beneath the scientific shell of today's scholar."

And it doesn't matter that, in this case, the true "beginning" evades us, that it may sought in "vain", that the so-called historical sciences, or more exactly the "palætiological" sciences, are incapable of reaching this goal [3: 8]. To grasp the fundamental origin of phenomena in general is only an ideal. It is in a sense a target for the mind. There remains the drive, the libido sciendi, which, on its own, creates a stir and is satisfied. As the physicist Jean-Marc Lévy-Leblond claims [4: 369]:

"The interest in science cannot be reduced to the petty aspirations for objective knowledge and the security it offers. There is in the thirst for knowledge [...] the expression of real passions and deepseated fantasies. When cosmology addresses the question of the origin of the universe, biology the origin of life, anthropology the origin of Man, science only reformulates in its own way the fundamental questionings of mankind, the quest for its identity, using all the intellectual means at its disposal: science meets the metaphysical and the mystical."

Since the $19^{\text {th }}$ century, although popular science has appealed to human emotion to the point of mixing up biblical narrative and modern rationalism based on Karl Popper's principle of falsification, the history of science has no hold on methodological psychologism. Subjectivity, what has sometimes been

\footnotetext{
${ }^{\text {a }}$ Corresponding author: blanckaertmc@wanadoo.fr
}

This is an Open Access article distributed under the terms of the Creative Commons Attribution License 4.0, which permits unrestricted use, distribution, and reproduction in any medium, provided the original work is properly cited. 
referred to as a re[searcher's personal equation, is certainly regaining its place in many learned texts that deal with the undecidable origin of the world, of life or of the "firstman" (cf. [5]). Anthropogenesis, in this respect, "becomes the pinnacle of genesis" [6: 5]. Nevertheless, semantics of the concept of origins vary greatly depending on the author and the era, ranging from creation to degree zero, formation or transformation. A psychological perspective does not add anything. These variable definitions and uses are the necessary starting point for understanding the economy of thoughts.

\section{The backstage of creation}

In $1750 \mathrm{La}$ Mettrie, epicurean doctor and sensationalist author of Man a Machine, touched upon the ongoing question of the "origin of animals", by formulating the hypothesis that there were in the air specific or virile "seeds" that were brought to life by heat before being absorbed and digested by the male body. Since the first men were not able to procreate, the bountiful Earth acted as a physical uterus. Furthermore, nature proceeding by trial and error and by chance as the Latin poet Lucretius suggested, there were many failures before achieving a viable organization, to the extent that, according to La Mettrie, only those that "were found to be endowed with all the [vital] parts" or those favoured by "the right combinations" survived. The "attempts" of matter at making man supposed the doggedness of a "blind cause" and the support of timelessness. Animals, less perfect than man, and instinctively primordial, "were formed first." La Mettrie's conjectural story ends with a claim of Pyrrhonian scepticism:

"So many Philosophers have upheld Epicurus' opinion that I dare add my feeble voice to theirs; like them, I have only created a System, which shows us what abyss one heads into, when with the desire to unveil the beginnings of time, one wishes to gaze presumptuously at what offers no foothold; because whether one accepts or rejects creation, it is the same mystery, the same bafflement" [7].

One would be wrong to take such "reflections" literally, and wrong to ignore them. Scholars of the Enlightenment commonly believed that the universe was a theatre where one only saw the set, hiding the back of the stage, the ropes and the counterweights. The desire to see behind the scenes of creation took hold of them. In fact, for anyone wishing to "lift the veil of nature" as one would a curtain, two hypotheses present themselves: either the world is the same today as it was yesterday, or its stability is an illusion.

A variation on the latter hypothesis is of course present in Buffon, whose fifth "epoch of nature" describes the primitive formation, some 15,000 years ago, of the most perfect species through the combination of "aqueous, oily and ductile" atmospheric matter into "organic molecules", which in turn moulded "organized bodies." Not without logic, Buffon thought that the largest species appeared first. For, on the one hand, the energy of nature was reputed to be at its most intense during the scalding period of terrestrial formation, and, on the other hand, the amount of organic molecules formed during this period of intense heat seemed sufficiently constant to be overwhelmingly monopolized by the strongest species at the expense of the weaker ones, which appeared later in colder conditions. One could say the latter only had left-overs [8: fifth epoch]. I recount these claims from the most renowned naturalist of the Enlightenment to stress that the heterogenic doctrines of the time did not apply direct formation solely to microscopic organisms. This became an imperative requirement only in the $19^{\text {th }}$ century. Around 1800 , it was still acceptable to conceive that the movements of matter had the power to give life to high-ranking species. For political reasons, Buffon exempted man from the events of this primordial "creation." Yet he admitted that from a bodily point of view, he did not fundamentally distinguish himself from other species, and that "his fate would have been more or less the same", and thus paid tribute to this "divine ray that the sovereign Being has imparted upon us" [8: 159-160]. His successors were not so evasive. In 1802, Pierre-Jean-Georges Cabanis, a revolutionary doctor from the Ideological school of thought, warned his readers: 


\section{ORIGINS}

"It is certain that individuals of the human race, other animals of the most perfect nature, and even plants of the highest order, form themselves before us only by means which have no bearing with the direct organization of inert matter: it does not ensue, however, that they could not be formed, and that they were not formed in the beginning, in an analogous manner to that which, even now, brings to life all these presently unknown new species of animalcules."

In other words, man is no different from the roughly sketched living organisms arising from the decomposition of mineral substances. "Once endowed with vital energy", they will go on to reproduce by ordinary generative means. Yet one cannot deduce from these their initial mode of appearance. Cabanis added, referring to the early discoveries by Cuvier of the globe's convulsions and of fossils, that man, having lived through these revolutions, could have undergone "important transformations, over centuries" [9: I: 519-524]. It goes almost without saying that this physical "origin" takes the place of the word of God the creator and does away with any "supernatural light": "mutability and death are no longer marks of inferiority and dependence but are in themselves conditions of the dynamism of Nature, perceived as an analogue of or substitute for divine intervention" [10: 25]. The riddle of the beginnings has no answer. For the same reasons, George Cuvier [11: 19, 20] saw forms perpetrated unchanged "since the beginning of all things." Unlike Cabanis or Lamarck, he pondered the "mystery of the pre-existence of germs." Cuvier therefore opted not only for a system of preformation, but also for the idea that each germ contained within it all the germs called to develop since the creation of life.

\section{The limits of reason}

After that, the anthropological structures pertaining to the origins paid scant attention to the violent criticisms, by scientists themselves, of those questions considered insoluble and henceforth of no interest. In the $19^{\text {th }}$ century, the question of origins, likened to an unconditioned cause, was declared contradictory and banned from discussions, like a verbal obstacle or a poetic trait. It was deemed inaccessible to any kind of experimental investigation and furthermore illogical. The philosopher and geographer Emmanuel Kant was one of the first to demonstrate this in his Critique of Pure Reason published in 1781 [12]. Human thought can only apprehend phenomena, meaning a series of effects that depend on prior causes. Therefore empirical intuition cannot grasp what is outside of time and outside of known conditions. Imagining the origin of the universe as a causality without a cause, of a different nature to what follows it [13], would amount to an ex nihilo creation, as a beginning determined only by the infinite power of God. The absolute origin, simple transcendental idea of a necessary first cause, is inaccessible to sensory knowledge. There is therefore, at this level of experience, something unknowable. And it would be a scientific conceit to act as legislator of the universe when human representation is limited to a constrained sequence of one thing to another.

Speculative reasoning was hit hard by Kant's restriction [12: book II, chap. II]. Kant himself abandoned his own "Theory of the Heavens", a cosmological synthesis with Newtonian leanings, which he first published in 1755 and which was considered "grandiose" by Ernst Haeckel more than a century later [14: $284 \mathrm{ff}$.] Nevertheless, the "natural study of the origins", pertaining to particular segments within a series of phenomena (for example the origin of human races or the geological history of the globe and its inhabitants) was not forbidden. Kant even invented in 1788 the neologism "physiogony" to designate a "history of nature" that put in order along a timeline a sequence of events linked to each other by their internal conditions. As for the rest, i.e. the crux of the matter, "the first origin of plants and animals", one might as well say the origin of species, it does not come under this type of empirical investigation. It is an altogether different matter, which exceeds our power. It would be, wrote Kant using the expression of Georg Forster, "a science for the Gods who had been present at creation, or who were even its authors, not a science for men" [15: 179-180].

One needs to emphasize these developments in critical thinking of the famous German philosopher. Beyond the ban affecting all research on the origin of the world, of life or of species, his reasoning 
in effect provided a desirable epistemological legitimacy to the new sciences of irreversible historical causes such as geology, palæontology, the development of languages and the formation of the solar system (cf. [16]). These were all controversial fields that were reintegrated at the beginning of the $19^{\text {th }}$ century within academia. Extending the Kantian charter in an idealist sense [17], William Whewell, professor of mineralogy and philosophy at Cambridge, called these fields "palætiological" [18: vol.1, book X]. Whewell belonged to the Anglican Church. He gave mutual assurances to reason, popular providentialism, and even to the theology of miracles: religion was required to provide the revelation of the origins, and in compensation the palætiological sciences were granted free inquiry of the mechanisms determining ulterior phenomena. Palætiological sciences were validated under this condition and exempt from suspicions of atheism. Whewell explained [18: 679] that none of these sciences were capable of coming up with "a beginning which is homogeneous with the known course of events." It was "not only an interruption, but an abyss, which interposes itself between us and any intelligible beginning of things." It was therefore possible to reconcile the divine commandment "let it be done", and its works. Science tells us nothing of the initial Creation [18: 687ff., 700-707].

Whilst in the $18^{\text {th }}$ century, as can be seen in numerous works on the knowledge of language or of man, "to resort to the origins allows one to apprehend clearly what would still exist today and under the same rules but in another state, less clearly represented" [19: 12, 20: 340], the turn of the century became receptive to the mystery of the "deep abyss of time." This was reinforced, if necessary, by the astounding discoveries in vertebrate palæontology, exemplified by the mammals of the Tertiary or the large saurians. One understands in this anxious context that the speculations of materialists were received with hostility. After the publication of his Zoological Philosophy in 1809 [21], Lamarck fell out of favour. By explaining that the first outlines of organization originated under damp conditions from the life-giving heat and electrical fluid of corpuscules, be they gelatinous (for animals) or mucilaginous (for plants), he gave the impression of talking nonsense. He was taken for an alchemist from another era.

And yet, unlike his predecessors, Lamarck was careful to lift any ambiguity. Spontaneous generation, or rather direct generation as he preferred to call it, gave life only to minute monads, near globules of life capable of sustaining, growing and reproducing themselves, which occurred only at the "bottom of the ladder" [21: vol. II, part 2, chap. VI]. It had never been the case, he insisted, that non-living matter had directly formed a rabbit, a bird, a fish or even an insect. These were complex animals that had arisen only by the usual means of generation [22:181], and which had undergone modifications through the power of development of life itself, their habits and the disruptive circumstances of their environment. And yet. Life loses all its secrets. It is a state of matter, a simple predicate. Nature has the ability to create "order and life in bodies devoid of them" [21: vol. II: 151]. Let us be clear. Lamarck was a deist. He denied being a materialist [23]. He neither professed the eternity of the world, nor the chance encounter of atoms, nor the unity of matter, life and consciousness. Simply, that the impenetrable darkness surrounding certain questions of origins disappeared outside the realms of reality. Already in 1802, suspecting reservations, he emphasized the significance of this type of inquiry:

"To try to seek, as a naturalist, what could be the origin of living bodies, and how they were formed, is a bold and reprehensible undertaking only in the eyes of the Philistine or of the ignorant, and not in the eyes of the true philosopher. It is not that especially in the eyes of he who is wise enough to not specify the way in which a supreme being, nature's creator, proceeded to bring all that exists to life" [24:56].

Without doubting in any way that Nature is "an order of created things, always active, all-powerful, immutable", Lamarck considered that all phenomena, without any possible exception, arose from the properties of matter and the laws that govern living things. At our level of understanding, nature dismisses the miracle which does not follow its principles. Life, wherever it comes from [25: 99-104], is not an entity in itself, and shining a supernatural light on it adds nothing to our understanding. Lamarck therefore believed he could catch nature in the act; since life, far from being created, was, like man, 


\section{ORIGINS}

only a product, it seemed possible to capture its emergence from a chain of supposedly "self-evident" relationships.

Lamarck had followers [26: $207 \mathrm{ff}$., $267 \mathrm{ff}$.] but for most scholars, he clearly overstepped the limits of prudent induction. Science could lay claim to its autonomy in the name of truth or progress. Was there any need though to invoke metaphysics? Lamarck made major contributions to invertebrate biology, and his works endured even though they were all adorned with this most personal "theory." In his obituary notice of Lamarck, Cuvier stated that "no one conceived their systematic part sufficiently dangerous to be made the subject of attack." The "system" in question, he conceded, could "amuse the imagination of a poet" but could not bear for a moment "the examination of anyone who has dissected a hand, a viscus, or even a feather!"

This alchemy of the origins was generally met with scepticism. In 1844, Auguste Comte opposed it to the positive spirit and asked for the permanent exclusion of "the insoluble questions which occupied the attention of our childhood" [27]. In other words, scholars who ventured there lost credibility. The concept of origins, with its exceptional or "revelatory" nature was seldom accepted to the extent that, even after Darwin, it was still the subject of many heated debates. The debate on heterogeny, which opposed from 1859 to 1864 Louis Pasteur to Félix Pouchet - two fixist scholars with marked religious orthodoxy - demonstrated that all discussion on the topic of origins was controversial. It transformed facts into values. Not without opportunism, Pasteur [28: 259] did not hesitate to link the fate of heterogeneous generation with the mysteries of creation which "have our best minds in thrall": "What a victory would be won by materialism, gentlemen, if it could cite in its support the demonstrable fact that matter organizes itself, brings itself to life." "The idea of God is useless"? The comfort of religion was not the only reason for the ongoing decline of research which sought to shed some light on the everyday workings of nature and on the darkness of the "beginnings." Science also contributed to this decline for good reasons. One must understand this rejection in science's own words, starting with the theory of organization, and what life, and the concept of species, meant to $19^{\text {th }}$ century naturalists.

\section{Less cannot lead to more}

In the $18^{\text {th }}$ century, it was still conceivable that an underlying life force was responsible for the growth of metals or that fibrous asbestos bridged the mineral and plant kingdoms. The familiar doctrine of the great chain of being, summed up by the adage "nature makes no leaps", was opposed in effect to a structural division of the different categories, and first to the individualization of living things. Their manifest properties, considered from a mechanical point of view, were not considered characteristic of another, no doubt superior, intelligible form. Organisms have often been viewed as machines. The apparent segmentation of the chain was therefore not insurmountable. The hierarchical order of creatures reflected the principle of plenitude of nature, and was the product of the physics of movement or of chemical associations. The turn of the $19^{\text {th }}$ century introduced a new scheme. Whatever the life-giving principle, "whirlwind", vital energy, Bildungstrieb, the organization of living things obeyed distinct laws of assimilation, growth, reproduction, and even sensitivity, that fall under, in the words of the doctor Paul-Joseph Barthez [29: I: 25] " a transcendental order compared to the laws of physics or mechanics." The life force of organs, he explained, showed itself to be "constantly superior" to what one would expect from the actions of ordinary causes [29: I: 85].

Of course, the definition of life itself had not improved. But it was seen as one with the association, sympathies and correspondences of organs in "a unique and closed system", according to Cuvier [30: 97]. Life was assimilated with, and determined by, the organization of its subordinate parts, which were mutually adjusted for adaptation. The idea of malleable "living matter" or that of "organic molecules" lost its persuasive force. The chain of being from minerals to man became discredited, creating space in the mind for what was to become "biology", the science of living bodies. Through recognition of the fixed nature of the organization of species, genera and embranchments, it was possible 
to dismiss the transformist hypothesis of the "alteration of forms" and moreover their common derivation "from a single one" [30: 112]. The foreclosure of the idea of origins also affected the hypothesis of spontaneous generation which could not be summarized by any known chemical process. If a constitutive correlation exists between life and organization, one leading to the other, then in the words of the anatomist Georges Cuvier [11: I: 17], the birth of organized beings remains the "greatest mystery of organic economy, and indeed of all nature":

"All the efforts of natural philosophers have never been able to discover matter either organizing itself, or organized by any external cause. Life, exercising upon the elements which compose a living body, and upon the particles which it attracts, an action contrary to that which ordinary chemical affinities would produce without it, affords us a convincing proof that it cannot be itself the result of any such affinities, and we are nevertheless ignorant of any other created power in nature capable of uniting particles which before were separate."

The colossal epigenesis that Lamarck and his successors stretched over time to the extreme, this double evolutionary series of plant and animal forms, went against all the regulatory notions on which this new natural history was founded. It was a logical heresy: it did not uphold the principle of species identity, the basic premise of taxonomy; a physiological heresy: the supposed emergence of complex organisms from simpler models would lead, according to Auguste Comte [27], "to suppose that there is more life where there is less organization"; an ontological heresy: the hypothesis of spontaneous generation contradicted the uniqueness of life itself and the fecund principle of organization; and finally an epistemological heresy: the classification of sciences based on the autonomous nature of their subject was undermined by physico-chemical reductionism. The status of comparative anatomy and physiology was at stake. It was better to put on hold any factual judgement pertaining to an apparently illusory problem without solution or empirical grounding. The final frontier of an emancipated science, the appearance of life was routinely devalued to a form of prescientific knowledge. Many thinkers of the $19^{\text {th }}$ century saw it as disguised metaphysics and made the point of distinguishing rigorous science from propaganda - either religious or materialist. As the positivist philosopher Auguste Comte [27: 3] pointed out, at its awakening, "the human mind directs its researches mainly toward the origin of things and toward the first and final causes of all the phenomena that it observes-in a word, toward absolute knowledge."

Perhaps Darwin was offended by this when he wrote his masterwork On the Origin of Species. As noted by many commentators, and despite its provocative title, Darwin did not address either origins or species. The Christian philosopher Etienne Gilson [31: appendix II] sensed a publishing strategy. Like his predecessors Buffon or Lamarck, Darwin was an authentic nominalist. He did not believe in species, and even less in their "creation." He used the word "precisely to deny it." The title of the book being misleading, one must see an implicit dismissal of the spiritual ideology of his contemporaries. The deception is even more apparent in Darwin's early notebooks, written between 1837 and 1838, were he confided that his "theory" of descent with modification contained a "whole metaphysics"; it would lead to the scrutiny of the "laws of change, which would then be main object of study, to guide our speculations with respect to past and future" [32: 177]. It is true that, at this point in his career, he still seemed to believe in some form of palingenesis [33: 155]. "If all men were dead," he notes, "then monkeys make men. Men make angels" [32: 140]. Ultimately, this opposition to religion did not lead to a complete disaffiliation. English morals, or more likely, a solid conviction of the worthlessness of spontaneous generation, made Darwin an expert in the art of being evasive. On the Origin of Species ends with a singular profession of faith for which Darwin has been criticised:

"There is grandeur in this view of life, with its several powers, having been originally breathed by the Creator into a few forms or into one; and that, whilst this planet has gone cycling on according to the fixed law of gravity, from so simple a beginning endless forms most beautiful and most wonderful have been, and are being evolved." 


\section{ORIGINS}

Darwin transgressed the rules of positivism with his theory of descent with modification. It was understood, as his opponents never tired of saying, that "what does less cannot do more" [34: II]. Although he made clear that it was "transformism that created fixism" [31: 55] (Gilson, 1971: 55), as an idealized counterpart and sole target of his attacks, Darwin never wanted, in the words of Littré [35: 446-447], "to go behind the curtains of life." He was not ignorant of the hiatus "that showed us that all living beings start off as a cell."

\section{Does nature make jumps?}

Emile Littré, an exemplary representative of positivism, refused to be caught in the debate between creation and evolution. For him, as for Auguste Comte, all notions of origin or finality were impenetrable to the human mind. These were "incognoscible" [35: 445], containing unknowns, and above all, masking their limitations, metaphysics of the worst kind. One might as well ask whether matter was eternal or created. The majority of positivists thought like him. The free spirit had to resist the pull of scholarly opinion. The hypothesis of panspermia from outer space, sometimes implied, could broaden our relative understanding of the universe. It was, however, at best pushing back the boundaries of current hypotheses. Rather than "leave nature facing a dilemma" [36: 166], it was preferable to "make nothing universal other than what can be known by experience" [35: 445]. In the 1870s, Littré divided his opponents by fighting against both the concept of spontaneous generation and transformism. If Lamarck and the "partisans" of heterogeny were "naturalists", Darwin was a "supernaturalist" [35: 444]. This was ultimately the same thing, since divine creation is, in a way, only another type of "heterogeneous generation." Positivism, retorted Littré [36: 72], "does not take sides with either of them." Indeed, the questions of origins can inspire man to dream, but they do not appeal to him.

It is worth clarifying that Darwin, the archetypal man of "origins", did not think differently. He avoided expressing his position on these grave matters in public. In later correspondence, he regretted having "truckled to public opinion" by using the term "creation", when he actually meant "appeared by some wholly unknown process." He nevertheless kept the term in subsequent editions of On the Origin of Species. He was, in the end, indifferent to the question. From his point of view, both were "rubbish thinking", whether one thought of the origin of life or of the origin of matter (Darwin letter to Joseph D. Hooker, March 29, 1863 [37: 306]). His position remained unresolved until the end. When reading in 1872 The Beginnings of Life by Henry Charlton Bastian, an advocate of "abiogenesis", Darwin was unconvinced by the arguments and blamed, not without diplomacy, "old convictions being stereotyped on [his] brain" (Darwin letter to Alfred R. Wallace, August 28, 1872 [37: 501-503]; cf. Strick [38: $72 \mathrm{ff}$. and 231, note 52]).

I insist on this point. The casting aside of the problems of "origins", followed by their tardy reintroduction in the cultural sphere, can only be accounted for by historical inquiry. There is nothing patent in their usage. As an example, the difficulties surrounding the hypothesis of spontaneous generation seemed insurmountable and the advantageous rediscovery of Lamarck's works after 1870 did not dispel any doubts. As life begets life, no one could conceive that it was possible to experimentally transform material forces into life-giving properties. If one admitted, alongside Clémence Royer [39: 670 , note], in the name of a logical requirement, that the planet suddenly had the power to "generate life" to the point of transforming itself into a giant nursery, would this not rehabilitate the miracle, "an unexpected whim, for which a sufficient reason would be only found afterwards" [40: 26]. It was better to go back to Diderot and imagine the eternal pre-existence of bricks of life, or life inherent to matter, or dispersed as germs in space ([41: 20-21]; $c f$. Diderot [41: 81-86]).

In truth, transformism has no need to be backed up by heterogenesis. Most English Darwinians, such as Thomas Henry Huxley, John Tyndall and even Herbert Spencer, supported the views of Pasteur [38: 20-22]. The confusion, however, served the controversy. In one instance, Darwin was criticized for not choosing between spontaneous generation and the hand of God; in another instance, enthusiastic 
readers of On the Origin of Species castigated Pasteur, a fervent catholic, and demanded that the issue be re-examined:

"the whole question of abiogenesis has entered upon quite a new stage and one far more favorable to the theory of its occurrence at the present time, in consequence of the influence of the famous Darwinian theory, and the investigations of Prof. Haeckel of Jena on the monera" [42: 147, note].

Darwin, deemed too cautious, seemed "incomplete." He stopped "in the middle of the chain of events" [39: XXX and XXXVII]. His disciple Ernst Haeckel, renowned zoologist and founder of a "complete" monistic philosophy, fared better in the German and French materialist circles. Hostile to Roman Catholicism, promoting the unity of force and matter, Haeckel used science to combat the idea of the duality of body and spirit. For him, life had no mysteries. It arose spontaneously as amorphous albuminous corpuscules from an elementary carbon-based protoplasm whose plasticity accounted for - must account for - evolution. Haeckel postulated the "unity of organic and inorganic nature" which excludes any vital force in favour of physico-chemical properties. Monera, the most rudimentary types of organisms, have "utter want of heterogeneous parts." There may well be no physiological phenomena that do not ultimately lead back to combinations of matter:

"The peculiar chemico-physical properties of carbon - especially the fluidity and the facility of decomposition of the most elaborate albuminoid compounds of carbon - are the sole and the mechanical causes of the specific phenomena of movement, which distinguish organic from inorganic substances, and which are called life, in the usual sense of the word".

Spontaneous generation, or "archigony", is deduced from the system. Although the vital synthesis has not been achieved artificially, it "has gained a degree of probability which entitles it to fill up the gap existing between Kant's cosmogony and Lamarck's Theory of Descent." In fact, Haeckel modernized the Lamarckian scheme more than he illustrated Darwin's prudent evolutionism [14: 290-304]. Thanks to his popular books, the boundaries between natural kingdoms being abolished, spontaneous generation, attacked on all fronts, became paradoxically a possibility again - a controversial possibility.

By his general explanation of the world, of pantheist persuasion, Haeckel set out to do away with all beliefs concerning God, freedom and substantial dualism which threatened his new religion: science. One type of belief drove out another. By confounding natural and moral laws, he garnered for a time the allegiance and support of free-thinking radicalism [43]. He made even more enemies among Catholic intellectuals, and would become their "bête noire", that is to say their best-cited antagonist up to the 1930s. Scientists have since nearly forgotten his name, yet he was the most accomplished advocate of spontaneous generation, an outdated yet major point of reference. The cleavage plane that divides materialists and idealists from a philosophical point of view appears to offer the historian an appropriate temporal framework. Here again, one is not so sure.

\section{On the principle of the excluded third: The conflict between faith and science}

We are familiar with updated versions of these themes, from the bubbling of molecules in the "brew kettle of the universe" to the birth of reflective thinking. Its relevance is in itself sufficient to warrant its examination. Beyond the recent scientific revolutions, which have, in the words of the historian Jacques Merleau-Ponty and the astronomer Bruno Morando [44: 17], made the idea of "origin" admissible once again "in the company of reputable concepts", it is important to place it in a historical context.

From the final quarter of the $19^{\text {th }}$ century onwards, history was rewritten under the influence of the conflict between faith and reason [45], for the origin of the universe as for the appearance of life on earth, which is the focus here. Haeckel's case reminds us that the debate is real and centres predominantly on the "Origins." But it is denatured by a series of simplistic reified antitheses, between creation and evolution, final cause and randomness, materialism and spiritualism. The Christian apologetics of the Third Republic were not in favour of the progress of Lamarckism, Spencer's evolutionism or scientific 


\section{ORIGINS}

free thought. Their adversaries were no less combative. There ensued a series of repetitive works, with either physico-theological tendencies, or monist tendencies in the Haeckelian vein, that could fill an entire library. Imprecations would pass as clarifications. In agreement with the principle of the excluded third, the human mind, internally divided, developed - one thought- two mutually exclusive tendencies "far back in time when man's curiosity tended towards questions of the composition, origin and evolution of the universe, of life and of man" [46: 1]. There were no loopholes. In this way, the two parties mentioned above admitted that science and religion existed in parallel, fuelling a silent, then open war between the defenders of tradition and those of modernity.

This historical perspective, too Manichean and simplistic, permeates even today many works of militant epistemology. It ignores the majority of "moderate" scholars, conciliators, who have never taken part in these venomous discussions. Draper neglected "intermediate opinions." He explained that only "extremists" "determine the issue" [45: VIII]. For the historian however, moderates are greater in number and academic status. Some lacked the will, or the opportunity, to debate with more extreme parties. It is worth mentioning the marked providentialism of a certain palæontological movement in France, from Albert Gaudry and Charles Depéret, to Pierre Teilhard de Chardin and his follower Jean Piveteau [47]; all renowned authors who either ignored, or wanted to resolve through dialectics the creation / evolution dichotomy.

That said, this episode of controversy was not inconsequential. It had repercussions and tended to repeat itself through the claims of religious fundamentalists. The dismissal of "transformist illusions", according to the common saying of 1900, was for a long time the subject of mostly philosophical studies, be they slim essays or doctoral theses, which refocused their arguments on the dominant question of "origins." Jean Rostand [48] bore witness to the public impact of these recurrent debates by expressing his rather surprising conviction that "the problem of the origin of life [...] was surely the gravest facing biology." Far from being confined to academic circles, these debates, by their impact, have become with time a real social phenomenon. Life arising from "non-life" remains an enigma that defies common sense, to the extent of polarizing minds and generating grandiloquent claims. It has more in common with the odyssey of the world and eschatology than to logical requirement. It is also a test of science's ability to fulfil its role in understanding the finality of humanity, against religion's claim of authority over individual consciences. In these terms, this antagonism is inevitable, as demonstrated by the debates of the second half of the $19^{\text {th }}$ century.

It was in this context of dramatized stakes that, in 1895, a daring and blistering pamphlet, written by the director of the Revue des Deux Mondes, member of the French Academy and literary critic Ferdinand Brunetière, was published [49]. The article was called "After a visit to the Vatican", a misleading title because there was no mention of Leon XIII but instead focused on his central thesis: the "failure" of science. Rationalistic and all-conquering, science had promised to do away with "the mystery." Yet it had stumbled on "the question of knowing where we come from"; it limited itself, for want of anything better, to the human animal without teaching us "what we are as human beings." Science had lost its prestige, and in the same stroke, "Religion had recaptured part of its own." Skilful publicist, Brunetière formulated this anathema and the famous controversy of "the bankruptcy of science" that inflamed spirits on both sides at the end of the $19^{\text {th }}$ century $[50,51]$. If one purposefully ignores his traditionalist slant, one notices that once again, Brunetière maintained a confusion that favoured his views, balancing origins with moral life, and archaeology of nature with philosophy of history. Science, he explained, strove to "reveal our nature, and from knowledge of our nature, reveal our destiny." Brunetière evoked for his own benefit the idea of a preformist determination of the origin common in the $18^{\text {th }}$ century, following the oft-repeated claim of Jean-Baptiste Vico [52: 66, §148] that the origin of things determines their natural dispositions, and vice versa. Time does not change that. If time can bring out the laws of a being that are present at its inception, it cannot alter these or generate new laws. "The growth of branches on a tree", comments Brunetière, "is not a 'modification' of the germ." Transformism being rejected for the same reason, the author gives his verdict: 
"We are surrounded by the unknowable, it cloaks us, it seizes us, we cannot derive from the laws of physics or the results of physiology any means of knowing it. [...] The radical powerlessness of science to resolve the question of origin and finality seems to have led to a cleavage dividing "scientific" certainty from "inspired" certainty [49: 99-100, 105, 110].

It is repeatedly said that "the question of origins exerts a unique fascination upon us" [6: 5]. In 1879, having translated Haeckel's Kingdom Protista, Jules Soury qualified this same question with little hesitation as "timeless." When all is considered, overdetermination of the origin would be an integral characteristic, independent from time, of the human mind. In which case, science would be "transfigured before our eyes by the great hopes that thinking humanity has placed upon it" [53: XVII]. One cannot fail to see the tendentious and performative aspect of this claim. It disqualifies the "fanciful" solutions of all the religious minds that seek a force outside the phenomenal conditions that dominate them, the "immaterial motives" (P. Bert, cited in [53: VI]).

The history of science has well-founded reasons to be wary of the eternalist nature of utterances. Not only has it been pointed out, time and time again, that the origins' absolute nature resists all scrutiny, but also that influential schools of thought, as was positivism in the $19^{\text {th }}$ century, rejected its inquiry with abstruse and out-of-date metaphysics, what Comte referred to as "the fictitious state." Origins have not always been an obsession of mankind. As for the investigation of life, the prevalent metaphor of the Enlightenment of the living machine, or the supposed analogy of the formation of animals, plants, minerals and metals that share, according to Maupertuis [54: 166], "similar origins" through juxtaposition of matter endowed with desires, aversions and memory..., resolve de facto the enigma of "transitions."

For a long time, crystal was used a model for organized beings. It is only with the exclusive definition of life as organization that the question of "hiatus" comes up. Cuvier bore witness to this. Despite this challenge, the $19^{\text {th }}$ century scholar continued - or could continue- to consider life as a crystallization process from the moment he rejected creation or the doctrine of vital force. In other words, "this rigorous separation that we allege between the organic and inorganic worlds is only an arbitrary distinction." No difference in "essence" separates them [42: 340].

Furthermore, the very existence of a statement does not imply its permanence [55: 138]. The questions of the past are not ours. This type of arbitration, always within the horizons of expectation, leads us to believe that science does not offer universal answers to the so-called obsessions of the collective unconscious. There is something that is not thought, and above all that is not thinkable. From our modernist point of view, Michel Foucault wrote [55: 340-41], "It is no longer origin that gives rise to historicity; it is historicity that, in its very fabric, makes possible the necessity of an origin which must be both internal and foreign to it: like the virtual tip of a cone in which all differences, all dispersions, all discontinuities would be knitted together so as to form no more than a single point of identity, the impalpable figure of the Same, yet possessing the power, nevertheless, to burst open upon itself and become Other."

From the word to the object, the ambiguity of origins is patent. It disregards experience. It calls upon extra-demonstrative figures of speech and as it is a constructed concept, it becomes interesting to study what is currently at stake now that the question of origins is topical again. Current debates take into account the decisive advances of science and technology that are said to have opened up the issue to empirical proof. It is the same argument that Jules Soury used, as described above. It is dubious.

If one considers the impenetrable cosmological Big Bang, one measures that the enthusiasm of researchers does not put an end to the conjectural factor, linked to the idea of totalization of the universe. The universe, as Gaston Bachelard said [56: 220] "is not an object", and apart from allowing a miracle (i.e. an "exceptional cause"), one cannot "follow in a linear fashion the causal flow." Many philosophers after him have repeated this: there are "suspicious" concepts and the origin is one of those [57: 77]. In other ways, "we are always guided by the awareness and the knowledge we have of the developed state of what we seek the beginning of. The beginning is always beginning of... So that the fact of origin 


\section{ORIGINS}

is never captured other than in the constituted and perfectly normalized field of the resulting chain of events" [58: 147-148].

In other words, proceeding backwards, the sequence of events is determined by its outcome. We accept as a given what is to be achieved, in the manner of Lamarck who describes the gradual organic "degradation" of organisms that fall to the bottom of the scale. Haeckel's reasoning is similar. This analytical method, commonplace in the $18^{\text {th }}$ century, proves to be if not sterile, at least artificial. Among other things, it supposes a rationality that is inherent to reality, an order of nature subjected to the determinism of laws and their infinitely repeatable and foreseeable effects. Necessity makes law. This is why advocates of spontaneous generation have always justified the actual production of organic sketches, which are prone to win their rank in the parade of species and become stabilized, by the "natural march of creation."

The critique by philosophers is misleading. Contemporary scientists have dismissed the Laplacian universe and have reintegrated in their equations the probabilism and contingency of events. One will speak from now on of "emergence thresholds", "self-organization", "fractal scale" or "rise in complexity." However, teleonomy can shatter, in the words of Jacques Monod, the "old animist alliance with nature" symbolized by cosmic finalism without abolishing the fictional dimension at the heart of even the most rigorous theories. Simply, as Monod confirmed regarding the first living systems [59: 179 and 185], the question of origins has "proved to be even more difficult than formerly thought." In particular, we have not yet broken the "sound barrier" by elaborating a "primitive cell" from a "prebiotic soup." "The field is open, too open"... And yet the author allows himself to dabble in "plausible" speculations. Once again, the "unknown" is in the conditional tense. Logical deduction makes up for what is lacking. When it strives for completeness, all scientific thought is an interpretation. It stirs the imagination. The arguments give order to reality to make it coherent.

As a finite empirical dataset can be explained by many competing theories or doctrines, one cannot choose between origin models based on their inventiveness. Their history, as we have seen, is but a long string of quarrels that cannot be resolved without solid narrative preconceptions. All in all, everyone chooses his own narrative between science(s) and religion(s). It is a lesson in relativism that is highlighted by the philosopher Jean Brun [60: 22, 23] when he unveils the "poetics" at work in modern naturalism: the physics of Anaximander, a pre-Socratic philosopher whose work has mostly been lost, has puzzled his commentators. We owe him the statement that "living creatures arose from the moist element as it was evaporated by the sun. Man was like another animal, namely, a fish, in the beginning." Was this, as was asked after 1870, a striking anticipation of Darwinian genealogy? Or, more disparagingly, did this formula hark back to Ancient Greek mythology? Jean Brun adds, in an exemplary turnaround:

"This would perhaps be the place to ask, as a conclusion, whether Darwinism does not meet Anaximander, not so much as a science but as an over-interpretation of the problem of origins. Anaximander tells a tale, one wonders afterwards whether he has observed; Darwin did observe, but one forgets to ask if, in the end, he also does not tell a tale."

I am very grateful to Dr. Hélène Citerne for her remarkable translation.

\section{References}

[1] F. Courtès, Pour une psychanalyse de l'évolutionnisme, In Hommage à Gaston Bachelard. Études de philosophie et d'histoire des sciences, pp. 161-189 (Paris, Presses universitaires de France, 1957)

[2] A. Leroi-Gourhan, Le geste et la parole. Technique et langage (Paris, Albin Michel, 1964)

[3] J. Piveteau, Origine et destinée de l'homme (Paris, Masson et cie, 1973) 
[4] J.M. Lévy-Leblond La science dans l'idéologie, In Philosopher. Les interrogations contemporaines, Christian Delacampagne, Robert Maggiori eds., pp. 365-380 (Paris, Fayard, 1980)

[5] C. Blanckaert, Les pièges de l'Origine. Imaginaire des commencements et science populaire, dans Origine de l'Homme : réalité, mythe, mode, Yves Coppens dir., pp. 147-170, (Paris, Eds Artcom', 2001)

[6] W. Stoczkowski, Aux origines de l'humanité (Paris, Pocket, 1996)

[7] J., Offray de La Mettrie, Réflexions philosophiques sur l'origine des animaux (1750), Corpus, $\mathrm{n}^{\circ}$ 5-6 [La Mettrie] : 167-179, (1987)

[8] G. Louis Leclerc de Buffon, Les époques de la Nature. Jacques Roger éd., Mémoires du Muséum national d'Histoire naturelle, $\mathrm{n}^{\text {elle }}$ série, série C, 10, (Paris, Ed. du Muséum, 1962)

[9] P.J.G. Cabanis, Rapports du physique et du moral de l'homme (éd. de 1805), dans CEuvres philosophiques, Claude Lehec, Jean Cazeneuve éds, t. i, pp. 105-631 (Paris, Presses universitaires de France, 1956)

[10] B., Balan, L'ordre et le temps. L'anatomie comparée et l'histoire des vivants au xixee siècle (Paris, Vrin, 1979)

[11] G. Cuvier, Le règne animal distribué d'après son organisation, pour servir de base à l'histoire naturelle des animaux et d'introduction à l'anatomie comparée. t. i. (Paris, Deterville, 1817)

[12] E. Kant, Critique de la raison pure. Trad. française A. Tremesaygues et B. Pacaud (Paris, Presses universitaires de France, 1971)

[13] G.W. Leibniz, De l'origine radicale des choses (1697), In Euvres de G.W. Leibniz, t. 1, pp. 338-345 (Lucy Prenant éd., Paris, Aubier Montaigne, 1972)

[14] E. Haeckel Histoire de la création des êtres organisés d'après les lois naturelles. Trad. Charles Letourneau ( $2^{\mathrm{e}}$ éd. Paris, C. Reinwald et Cie, 1877)

[15] E. Kant «Sur l'emploi des principes téléologiques dans la philosophie » (1788), dans $L a$ philosophie de l'histoire, pp. 173-211 (Stéphane Piobetta trad. et éd., Paris, Aubier-Montaigne, 1947)

[16] G. Gohau, S. Tirard, (ed.), Les sciences des causes passées, Cahiers François Viète, n 9-10 (2005)

[17] R. Yeo, William Whewell, natural theology and the philosophy of science in mid nineteenth century Britain, Annals of Science, 36: 493-516 (1979)

[18] W. Whewell, The Philosophy of the Inductive Sciences founded upon their History ( $2^{\mathrm{e}}$ éd. 1847) (John Herivel éd., New York-Londres, Johnson Reprint Corporation, 1967)

[19] C. Limoges Introduction In Carl Linné, L'équilibre de la nature, trad. Bernard Jasmin, pp. 7-22 (Paris, Vrin, 1972)

[20] M. Foucault, Les mots et les choses. Une archéologie des sciences humaines (Paris, Gallimard, 1966)

[21] Jean-Baptiste Monet de Lamarck, Philosophie zoologique ou exposition des considérations relatives à l'histoire naturelle des animaux (1809), ( $\mathrm{N}^{\text {elle }}$ éd., Charles Martins éd., Paris, F. Savy, 1873)

[22] Jean-Baptiste Monet de Lamarck, Inédits de Lamarck d'après les manuscrits conservés à la Bibliothèque centrale du Muséum national d'Histoire naturelle de Paris. Max Vachon, Georges Rousseau, Yves Laissus eds. (Paris, Masson et cie, 1972)

[23] M.J.S. Hodge, La métaphysique de Lamarck d'après un opuscule retrouvé, Revue d'histoire des sciences, 26(3): 223-229 (1973)

[24] Jean-Baptiste Monet de Lamarck, Recherches sur l'organisation des corps vivants (1802), (Paris, Fayard, 1986)

[25] S. Tirard, Générations spontanées In P. Corsi, J. Gayon, G. Gohau, S. Tirard, Lamarck, philosophe de la nature, pp. 65-104 (Paris, Presses universitaires de France, 2006) 


\section{ORIGINS}

[26] P. Corsi, Lamarck. Genèse et enjeux du transformisme 1770-1830. Trad. Diane Ménard (Paris, Éditions du CNRS, 2001)

[27] A. Comte, Discours sur l'esprit positif. Ordre et progrès (1844), (Paris, Vrin, 1974)

[28] L. Pasteur, Des générations spontanées, Revue des cours scientifiques de la France et de l'étranger, $1^{\text {ère }}$ année, $\mathrm{n}^{\circ}$ 21: 257-265 (1864)

[29] P.J. Barthez, Nouveaux élémens de la science de l'Homme (1778). $2^{\mathrm{e}}$ éd. revue et aug. (Paris, Goujon et Brunot, 1806)

[30] G. Cuvier, Recherches sur les ossements fossiles de Quadrupèdes où l'on établit les caractères de plusieurs espèces d'animaux que les révolutions du globe paraissent avoir détruites. Discours préliminaire (1812). Pierre Pellegrin éd. (Paris, GF-Flammarion, 1992)

[31] E. Gilson, D’Aristote à Darwin et retour. Essai sur quelques constantes de la biophilosophie (Paris, Vrin, 1971)

[32] C. Darwin, Le corail de la vie. Carnet B (1837-1838). Trad. Maxime Rovere (Paris, PayotRivages, 2008)

[33] C. Bonnet, La Palingénésie philosophique ou idées sur l'état passé et sur l'état futur des êtres vivans (éd. 1783), (Paris, Fayard, 2002)

[34] L. Vialleton, L'origine des êtres vivants. L'illusion transformiste (Paris, Plon, 1929)

[35] E. Littré, De quelques questions soulevées à propos du transformisme, La philosophie positive, t. xv : 441-448 (1875)

[36] E. Littré, L'hypothèse de la génération spontanée et celle du transformisme doivent-elles être incorporées à la partie biologique de la philosophie positive ? La philosophie positive, t. xxii : 165-180 (1879)

[37] C. Darwin, La vie et la correspondance de Charles Darwin avec un chapitre autobiographique publiés par son fils M. Francis Darwin. Trad. Henry C. de Varigny, (Paris, Reinwald, 1888)

[38] J.E. Strick, Sparks of Life. Darwinism and the Victorian debates over spontaneous generation, (Cambridge-Londres, Harvard University Press, 2002)

[39] C. Royer, Préface du traducteur et Notes, dans Charles Darwin, De l'origine des espèces ou des lois du progrès chez les êtres organisés, pp. v-lxiv et passim, (Paris, Guillaumin et Cie, V. Masson et fils, 1862)

[40] E. Dally, Introduction, In T.H. Huxley, De la place de l'homme dans la nature, pp. 1-96 (Paris, J.-B. Baillière et Fils, 1868)

[41] D. Diderot, Entretien entre D’Alembert et Diderot. Le rêve de d'Alembert. Jacques Roger éd. (Paris, Garnier-Flammarion, 1965)

[42] L. Büchner, Force et matière. Études populaires d'histoire et de philosophie naturelles. $5^{\mathrm{e}}$ éd. (Paris-Leipzig, C. Reinwald-Théodore Thomas, 1876)

[43] C. Blanckaert, L'impartiale Critique de la raison mûre... Évolution, libre pensée et monisme à la française, [Heiko Weber, Maurizio di Bartolo dir.] Jahrbuch für Europäische Wissenschaftskultur / Yearbook for European Culture of Science, 3: 135-164 (2007)

[44] J. Merleau-Ponty, B. Morando, Les trois étapes de la cosmologie. (Paris, Robert Laffont, 1971)

[45] J.W. Draper, Les conflits de la science et de la religion (Paris, Germer Baillière et Cie, 1882)

[46] J.M.A.L dit Jean-Louis de Lanessan, Transformisme et créationisme. Contribution à l'histoire du transformisme depuis l'antiquité jusqu'à nos jours (Paris, F. Alcan, 1914)

[47] C. Grimoult, Le développement de la paléontologie contemporaine (Genève, Droz, 2000)

[48] J. Rostand, La genèse de la vie. Histoire des idées sur la génération spontanée (Paris, Hachette, 1943)

[49] F. Brunetière, Après une visite au Vatican Revue des deux Mondes, 127, livraison du $1^{\mathrm{er}}$ janvier : 97-118 (1895)

[50] H.W. Paul, The debate over the bankruptcy of science in 1895, French Historical Studies 5(3): 299-327 (1968) 
[51] A. Rasmussen, Critique du progrès, « crise de la science : débats et représentations du tournant de siècle », Mil neuf cent, $\mathrm{n}^{\circ}$ 14: 89-113 (1996)

[52] G. Vico, Principes d'une science nouvelle relative à la nature commune des nations (1744). Trad. Ariel Doubine (Paris, Nagel, 1953)

[53] J. Soury, Introduction du traducteur In Ernst Haeckel, Le Règne des Protistes. Aperçu sur la morphologie des êtres vivants les plus inférieurs (Paris, C. Reinwald et Cie, 1879)

[54] P.L. Moreau de Maupertuis, Systême de la Nature In CEuvres, Lyon, t. ii, pp. 135-184 (1768)

[55] M. Foucault, L'Archéologie du savoir (Paris, Gallimard, 1969)

[56] G. Bachelard, L'activité rationaliste de la physique contemporaine. $2^{\mathrm{e}}$ éd. (Paris, Presses universitaires de France, 1965)

[57] L. Althusser, E. Balibar, Lire Le Capital. Vol. I (Paris, F. Maspero, 1980)

[58] J.T. Desanti, Les idéalités mathématiques. Entretien avec Jean-T. Desanti, Épistémologie et marxisme, pp. 143-160 (Paris, Union générale d'éditions, 10/18, 1972)

[59] J. Monod, Le hasard et la nécessité. Essai sur la philosophie naturelle de la biologie moderne (Paris, Seuil, Points, 1973)

[60] J. Brun, Les Présocratiques. $2^{e}$ éd. revue (Paris, Presses universitaires de France, 1973) 